\title{
Optimization of High-Performance Liquid Chromatography Parameters for Purification of Oligonucleotide-A
}

\author{
Christina Perez, Mubeen Rani, Tuan Phan \\ Department of Chemistry, Texas Southern University, Houston, USA \\ Email: Tuan.Phan@tsu.edu
}

How to cite this paper: Perez, C., Rani, M. and Phan, T. (2022) Optimization of HighPerformance Liquid Chromatography Parameters for Purification of Oligonucleotide-A. American Journal of Analytical Chemistry, 13, 39-50.

https://doi.org/10.4236/ajac.2022.132004

Received: October 26, 2021

Accepted: February 25, 2022

Published: February 28, 2022

Copyright $\odot 2022$ by author(s) and Scientific Research Publishing Inc. This work is licensed under the Creative Commons Attribution International License (CC BY 4.0).

http://creativecommons.org/licenses/by/4.0/

(c) (i) Open Access

\begin{abstract}
The modification of high-performance liquid chromatography parameters leads to a more effective oligonucleotide-A purification process. Using various experimental parameters such as buffer, concentration, and $\mathrm{pH}$, a method for optimizing the purification of an oligonucleotide- $\mathrm{A}$ on a reverse-phase C18 column was created. To purify oligonucleotide-A, High-Performance Liquid Chromatography (HPLC), Ultraviolet-Visible Spectrophotometry (UV-Vis), Liquid Chromatography-Mass Spectrometry (LC-MS), and lyophilization were used. Chromatographic data were collected with a semi-prep HPLC system, quantified with the UV-Vis technique, and validated with the LC-MS method. The most optimized parameters found to obtain the purity of $93.0 \%$ are $40 \mathrm{mM}$ triethylammonium bicarbonate (TEAB) buffer with $\mathrm{pH} 7$, which is approximately $6.0 \%$ higher than the reported method of which the purity is $87.0 \%$. However, the yield under these conditions was reduced by about $5 \%$. The worst possible optimized settings that resulted in the lowest purity $(84.0 \%)$ and yield $(69.0 \%)$ are $10 \mathrm{mM}$ ammonium acetate $\left(\mathrm{NH}_{4} \mathrm{CH}_{3} \mathrm{CO}_{2}\right)$ with $\mathrm{pH} 7$.
\end{abstract}

\section{Keywords}

Purification, High-Performance Liquid Chromatography, Oligonucleotide-A, Dipotassium Phosphate, Triethylammonium Acetate, Triethylammonium Bicarbonate, Ammonium Acetate

\section{Introduction}

Synthetic oligonucleotides have evolved into important biomolecules with a wide range of applications. Purification and modification of synthetic oligonucleotides are critical technologies for a wide range of applications in the life sciences [1]. 
Synthetic oligonucleotides have been used in DNA sequencing as hybridization probes, linkers, and primers, as well as in amplification procedures and antisense therapies [2]. One of the most serious issues with synthetic oligonucleotides is impurity, which can result from poor synthesis, de-protected products, short sequences, and/or changed sequences [3] [4]. These contaminants can jeopardize an experiment or assay in some cases by competing with full-length products or inhibiting reactions [5].

Oligonucleotide purification approaches (optimizing $\mathrm{pH}$, concentration, mobile phase, and chain) have been developed to increasing functionalization in a variety of genomic assays and pharmacological treatments [6]. The most common purification processes are Thin-Layer Chromatography (TLC), purification cartridges, Polyacrylamide Gel Electrophoresis (PAGE) gels, desalting, and HighPerformance Liquid Chromatography (HPLC). As laboratories strive for greater efficiency, a focus on increasing yields and shortening purification times has grown in importance [7]. Several parameters, including the application, oligonucleotide length, and oligonucleotide alterations, determine the best approach [8] [9]. HPLC is one of the purification methods that can be used on a large scale to separate oligonucleotides. Among the many HPLC procedures available are Reverse-Phase (RP), Normal-Phase (NP), Hydrophilic Interaction (HI), Ion-Exchange (IE), and Size-Exclusion (SE). All of these strategies apply to the stationary phase of the system.

To fully comprehend the retention mechanism influencing a separation, the chemistry of the bonded phase, the nature of the silica surface treatment, and the surface accessibility must all be considered and classified, which will then influence the initial column selection or method optimization [10] [11] [12]. HPLC parameters have an effect on the chromatogram, which is the final product of the HPLC experiment. The detector response is a time-dependent function of the chromatogram [13]. In HPLC, the resolution of the chromatogram is the most important factor. The goal is to achieve the best possible resolution in the shortest possible time. A resolution of 1.5 or higher ensures that the sample components are well separated enough to determine the area under the curve correctly [14].

When developing HPLC procedures, the first approach frequently fails to separate key components of a mixture. To achieve the required separations, the mobile phase, stationary phase, and column temperature can all be adjusted [15]. Changing the particle size of the column is another useful parameter. Greater plate numbers are produced by smaller particle sizes, resulting in sharper peaks and the ability to resolve closely eluting peaks [16]. Some components, such as proteins and oligonucleotides, may be difficult to separate on smaller columns but can be resolved fast on a larger column [17]. Other factors that determine chromatogram resolution include selectivity, efficiency, and retention, which are regulated by HLPC parameters (solvent strength, $\mathrm{pH}$, column material, and temperature) [18].

This paper provides a thorough assessment of oligonucleotide-A purification 
in terms of purity and yield. HPLC parameters such as buffer, concentration, and $\mathrm{pH}$ were used to find the best purification procedure.

\section{Experimental}

\subsection{Materials}

The sample in all separation experiments was a 30-mer oligonucleotide-A. The crude oligonucleotide-A obtained from IDT (USA) had a molecular weight of 9513. Reagent grade $1 \mathrm{M}$ Tris $\mathrm{HCl}$, acetonitrile, phosphate-buffered saline (PBS), and $\mathrm{NaCl}$ were supplied by VWR (USA). The on-site MilliQ system provided deionized water for the research (NANOPure). The chromatography stationary phase for the initial research was a Dionex DNAPac PA200 oligonucleotide column $(4 \times$ $250 \mathrm{~mm}$ ). Before purification, all samples were examined on an Agilent 1260 analytical HPLC system. A $500 \mathrm{nmol}$ of stock oligonucleotide-A was diluted to $1 \mathrm{mM}$ in $10 \times$ PBS. To attain incoming purity, one nanomole of oligonucleotide-A was run on the PA200 column. After running the sample through the HPLC system, a mass was recorded using an Agilent 6100 series SQ system to confirm the product. The initial parameters in Table 1 show the analysis method used to record initial purity. The purity was documented, and the sample was readied for purification.

\subsection{Initial Control}

The preparative chromatographic studies were carried out on a ChemStation Work Station that was linked to an Agilent 1260 semi-prep HPLC system equipped with a diode array detector. Table 2 shows the experimental parameters that are being modified and tested. Each variant change was tested three times, with the given result being the average of the three runs. The first stage in the optimization process was to replicate the results provided in the literature, which showed that HPLC employing potassium phosphate buffer at $\mathrm{pH} 7$ and acetonitrile yielded $88.0 \%$ purity and $80.00 \%$ recovery [1]. For peaks greater than $300 \mathrm{mAU}$, a shallow gradient was applied to an XTERRA C18 column $(19 \times 100 \mathrm{~mm})$, and fraction collection was utilized.

Table 1. Initial IEC analysis gradient.

\begin{tabular}{ccc}
\hline Time, min & $\begin{array}{c}\mathrm{K}_{2} \mathrm{HPO}_{4} \%: 100 \mathrm{mM} \text { Tris } \mathrm{HCl} \\
+25 \% \text { Acetontrile }\end{array}$ & $\begin{array}{c}\text { TEAB \%: } 100 \mathrm{mM} \text { Tris } \mathrm{HCl}+ \\
25 \% \text { Acetonitrile }+1.25 \mathrm{M} \mathrm{NaCl}\end{array}$ \\
\hline 0 & 100 & 0 \\
30 & 50 & 50 \\
31 & 50 & 0 \\
33 & 100 & 0 \\
36 & 100 & 0
\end{tabular}


Table 2. Testing parameters for each experiment.

\begin{tabular}{|c|c|c|c|c|c|c|}
\hline Constant & Constant & Variant & Variant & Variant & Variant & Variant \\
\hline $\mathrm{K}_{2} \mathrm{HPO}_{4}$ & $10 \mathrm{mM}$ & pH 5 & pH 6 & pH 7 & pH 8 & pH 9 \\
\hline $\mathrm{K}_{2} \mathrm{HPO}_{4}$ & $20 \mathrm{mM}$ & pH 5 & pH 6 & pH 7 & pH 8 & pH 9 \\
\hline TEAB & $40 \mathrm{mM}$ & pH 5 & pH 6 & pH 7 & pH 8 & pH 9 \\
\hline TEAB & $\mathrm{pH} 7$ & $1 \mathrm{mM}$ & $10 \mathrm{mM}$ & $20 \mathrm{mM}$ & $30 \mathrm{mM}$ & $40 \mathrm{mM}$ \\
\hline $\mathrm{K}_{2} \mathrm{PO}_{4}$ & pH 7 & $1 \mathrm{mM}$ & $10 \mathrm{mM}$ & $20 \mathrm{mM}$ & $30 \mathrm{mM}$ & $40 \mathrm{mM}$ \\
\hline $10 \mathrm{mM}$ & pH 7 & $\mathrm{~K}_{2} \mathrm{PO}_{4}$ & TEAA & TEAB & $\mathrm{NH}_{4} \mathrm{CH}_{3} \mathrm{CO}_{2}$ & \\
\hline TEAB & $\mathrm{pH} 7,40 \mathrm{mM}$ & Oligo-20 & Oligo-25 & Oligo-30 & Oligo-35 & Oligo-40 \\
\hline
\end{tabular}

Note: Each variant was run three times, the average of the three is reported in this work.

\subsection{Rotary Evaporation}

In-process samples from potassium phosphate buffer preparative runs at $\mathrm{pH} 5$ to 9 were kept in the refrigerator at $4^{\circ} \mathrm{C}$. After that, the samples were concentrated using a Heidolph Precision rotary evaporator. The bath temperature was set at $30^{\circ} \mathrm{C}$, and the rotation speed was set to $100 \mathrm{rpm}$. The pressure was manually controlled, and it took roughly 75 minutes for one sample to evaporate from $40 \mathrm{~mL}$ to $2 \mathrm{~mL}$.

\subsection{Lyophilization}

A FreeZone Freeze Dry System was used to lyophilize the material. The leftover sample is frozen using dry ice and isopropanol alcohol after each sample has been evaporated close to dryness, $2 \mathrm{~mL}$. This procedure takes approximately 5 minutes. The sample is placed on the Freeze Dry System overnight when it has totally frozen. The material was returned to powder form the following morning. After that, the sample is reconstituted in $10 \times$ PBS buffer.

\subsection{Quantification Using Spectrophotometer}

After the material has been restored to liquid form, it is quantified. The quantification is done using a Biotek Synergy H1 spectrophotometer with the extinction coefficient of the oligonucleotide-A provided by IDT. The coefficient of extinction was $363,400 \cdot \mathrm{M}^{-1} \cdot \mathrm{cm}^{-1}$. The following calculation was used to determine concentration:

$$
\text { Concentration in } \mathrm{uM}=\left(\left(\frac{\text { Absorbance } * \text { Dilution Factor }}{\text { Extinction. Coefficient }}\right) / t\right) * 1,000,000
$$

\subsection{Reanalysis}

The final step in the procedure is reanalysis on an Agilent 1260 analytical HPLC system and verification on an Agilent 6100 Series SQ LC/MS system. 


\section{Result and Discussion}

Table 2 shows the experiment designed to investigate this work. Buffer type, buffer concentration, and buffer $\mathrm{pH}$ are factors that affecting the purification of oligonucleotide-A. Keeping two factors constant and changing either buffer type, buffer concentration, or buffer $\mathrm{pH}$, purity and yield were determined.

\section{1. pH Optimization}

Table 3 lists all \% purity values and yields with different $\mathrm{pH}$ values (5 to 9 ) at constant $10 \mathrm{mM} \mathrm{K}_{2} \mathrm{HPO}_{4}, 20 \mathrm{mM} \mathrm{K}_{2} \mathrm{HPO}_{4}$, and $40 \mathrm{mM}$ TEAB. Figure 1(a) compares the percent purity and yield of $\mathrm{K}_{2} \mathrm{HPO}_{4}$ at $10 \mathrm{mM}$, Figure 1 (b) for $\mathrm{K}_{2} \mathrm{HPO}_{4}$ at $20 \mathrm{mM}$, and Figure 1 (c) for TEAB at $40 \mathrm{mM}$, with $\mathrm{pH}$ values ranging from 5 to 9 .

When the concentration of $\mathrm{K}_{2} \mathrm{HPO}_{4}$ was kept constant at $10 \mathrm{mM}$ and $\mathrm{pH}$ 7, the purity was $87.5 \%$ and the yield was $79.0 \%$, which stayed at the optimum level. However, lowering the $\mathrm{pH}$ results in a decrease in purity and yield. The purity of the sample was $86.0 \%$ at $\mathrm{pH} 6$ and $85.9 \%$ at $\mathrm{pH} 5$, with yields of $78.8 \%$ and $78.0 \%$. This value is $1 \%-2 \%$ lower than $\mathrm{pH}$ 7. The purity was $86.9 \%$ and $87.0 \%$, respectively, and the yield was $79.1 \%$ and $78.9 \%$ at higher $\mathrm{pH} 8$ and 9 but did not produce a greater purity and yield at this $\mathrm{pH}$.

Table 3. Comparison of purity and yield with different $\mathrm{pH}$ values for Oligonucleotide- $\mathrm{A}$ at constant $10 \mathrm{mM}$ and $20 \mathrm{mM}$ concentrations of $\mathrm{K}_{2} \mathrm{HPO}_{4}$ and constant $40 \mathrm{mM}$ concentration of TEAB with $\mathrm{pH}$ ranging from 5 to 9 .

\begin{tabular}{|c|c|c|c|c|}
\hline $\mathrm{pH}$ & Buffer & Concentration, $\mathrm{mM}$ & Purity, \% & Yield, \% \\
\hline \multirow[t]{3}{*}{5} & $\mathrm{~K}_{2} \mathrm{HPO}_{4}$ & 10 & $85.9 \pm 0.2$ & 78.0 \\
\hline & $\mathrm{K}_{2} \mathrm{HPO}_{4}$ & 20 & $86.3 \pm 0.2$ & 78.1 \\
\hline & TEAB & 40 & $93.0 \pm 0.3$ & 75.1 \\
\hline \multirow[t]{3}{*}{6} & $\mathrm{~K}_{2} \mathrm{HPO}_{4}$ & 10 & $86.0 \pm 0.1$ & 78.8 \\
\hline & $\mathrm{K}_{2} \mathrm{HPO}_{4}$ & 20 & $86.7 \pm 0.2$ & 77.9 \\
\hline & TEAB & 40 & $93.7 \pm 0.3$ & 75.7 \\
\hline \multirow[t]{3}{*}{7} & $\mathrm{~K}_{2} \mathrm{HPO}_{4}$ & 10 & $87.5 \pm 0.5$ & 79.0 \\
\hline & $\mathrm{K}_{2} \mathrm{HPO}_{4}$ & 20 & $87.7 \pm 0.2$ & 77.9 \\
\hline & TEAB & 40 & $93.9 \pm 0.1$ & 74.5 \\
\hline \multirow[t]{3}{*}{8} & $\mathrm{~K}_{2} \mathrm{HPO}_{4}$ & 10 & $86.9 \pm 0.3$ & 79.1 \\
\hline & $\mathrm{K}_{2} \mathrm{HPO}_{4}$ & 20 & $87.4 \pm 0.3$ & 77.8 \\
\hline & TEAB & 40 & $93.3 \pm 0.1$ & 74.5 \\
\hline \multirow[t]{3}{*}{9} & $\mathrm{~K}_{2} \mathrm{HPO}_{4}$ & 10 & $87.0 \pm 0.1$ & 78.9 \\
\hline & $\mathrm{K}_{2} \mathrm{HPO}_{4}$ & 20 & $87.3 \pm 0.1$ & 77.5 \\
\hline & TEAB & 40 & $93.1 \pm 0.1$ & 74.1 \\
\hline
\end{tabular}

Note: Each value is obtained based on the average of three runs. 


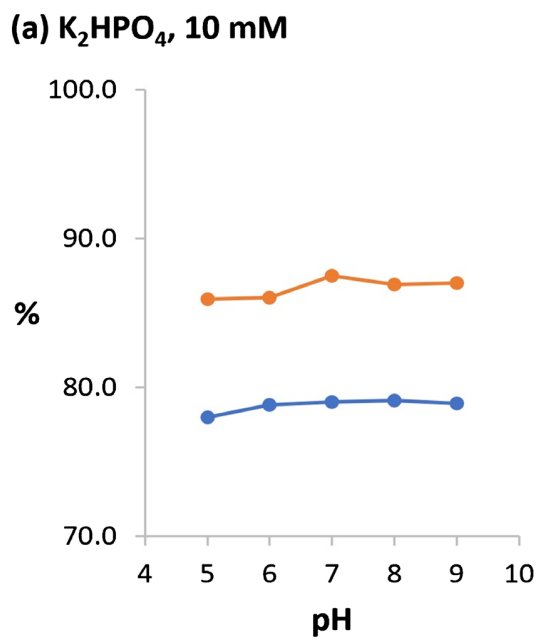

(b) $\mathrm{K}_{2} \mathrm{HPO}_{4}, 20 \mathrm{mM}$

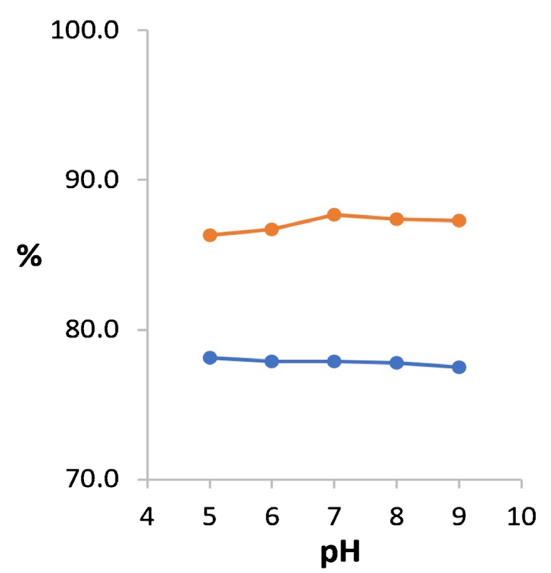

(c) TEAB, $40 \mathrm{mM}$

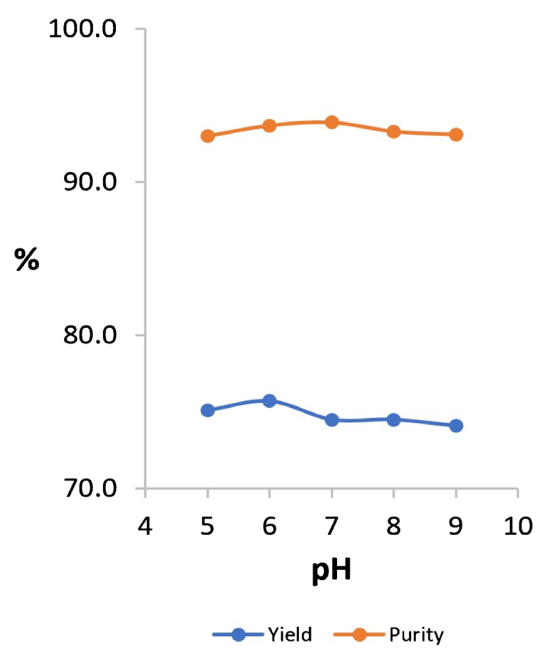

Figure 1. Comparison of the purity and yield percentages of $\mathrm{K}_{2} \mathrm{HPO}_{4}(10$ and $20 \mathrm{mM})$ and TEAB (40 mM) with $\mathrm{pH}$ ranging from 5 to 9.

Changing the concentration of $\mathrm{K}_{2} \mathrm{HPO}_{4}$ from 10 to $20 \mathrm{mM}$ and then varying the $\mathrm{pH}$ from 5 to 9 resulted in no improvement in oligonucleotide-A purification at a constant $20 \mathrm{mM}$ concentration of $\mathrm{K}_{2} \mathrm{HPO}_{4}$. The $\mathrm{pH} 7$ sustained optimum 
values reveal the same purity and yield as $10 \mathrm{mM}$ in the previous method as $87.7 \%$ and $77.9 \%$, respectively. The overall purity at pH 6 and 5 was $86.7 \%$ and $86.3 \%$, respectively, in the experiment, although the overall yield was $77.9 \%$ and $78.1 \%$.

Yield was shown to decrease by 1.6 percent when the $\mathrm{pH}$ climbed from $\mathrm{pH} 5$ to $\mathrm{pH}$ 9. The purity of oligonucleotide- $\mathrm{A}$ increased by 0.2 percent at $20 \mathrm{mM}$ concentration and $\mathrm{pH} 7$ compared to $10 \mathrm{mM}$ concentration and $\mathrm{pH}$ 7. Yield, on the other hand, fell by 0.5 percent.

When the dipotassium phosphate buffer $\mathrm{pH}$ variation was compared, the results from the $20 \mathrm{mM}$ concentration studies were all slightly higher than the results from the $10 \mathrm{mM}$ concentration experiments. There was a $0.2 \%-0.7 \%$ higher in purity at $20 \mathrm{mM} \mathrm{K}_{2} \mathrm{HPO}_{4}$ across $\mathrm{pH} 5$ - $\mathrm{pH}$ 9. However, increased $\mathrm{K}_{2} \mathrm{HPO}_{4}$ concentrations resulted in a $0.2 \%-1.4 \%$ decline in output.

When the buffer was changed from $\mathrm{K}_{2} \mathrm{HPO}_{4}$ to TEAB at $40 \mathrm{mM}$, the $\mathrm{pH}$ had a significant impact on the results. The purity and yield $(93.3 \%$ and $74.5 \%$, respectively) at $\mathrm{pH} 8$ were equivalent to $\mathrm{pH} 9(93.15 \%$ and $74.1 \%)$ at the same concentration; however, when compared to $\mathrm{K}_{2} \mathrm{HPO}_{4}$ at $10 \mathrm{mM}$, the purity increased by $6.1 \%$ while the yield decreased by $4.8 \%$. When compared to $\mathrm{K}_{2} \mathrm{HPO}_{4}$ at $20 \mathrm{mM}$, the purity increased for TEAB at $\mathrm{pH} 8$ and 9, but the yield was somewhat reduced.

When $\mathrm{pH} 5$ and 6 were used with TEAB, the yields (93.0\% for $\mathrm{pH} 5$ and $93.7 \%$ for $\mathrm{pH}$ 6) were significantly higher (7.1 to 7.8\%) than when $\mathrm{pH} 5$ and 6 were used with $\mathrm{K}_{2} \mathrm{HPO}_{4}$. However, at the same $\mathrm{pH}$ levels, the yields were roughly $2.0 \%$ lower than with $\mathrm{K}_{2} \mathrm{HPO}_{4}$. TEAB at $40 \mathrm{mM}$ and $\mathrm{pH} 7$ produced the highest purity (93.9\%); nonetheless, the percent yield is comparable to other $\mathrm{pH}$ values of the same buffer.

The standard deviation was calculated in these tests to quantify the amount of variation across all three trials at each $\mathrm{pH}$ level. All results were considered low, with the maximum standard deviation in the data set being 0.36 at $\mathrm{pH} 8$ with 10 $\mathrm{mM} \mathrm{K}_{2} \mathrm{HPO}_{4}$. The data set's lowest standard deviation was 0.10 , which was observed at $\mathrm{pH} 8$ and $\mathrm{pH} 9$.

\subsection{Concentration Optimizations}

According to the data in Table 3, at $\mathrm{pH} 7$, both buffers $\left(\mathrm{K}_{2} \mathrm{HPO}_{4}\right.$ and TEAB) produce the best outcomes when compared to the same concentration at other $\mathrm{pH}$ levels. This section explains the findings obtained when the buffer concentration varies from 1 to $40 \mathrm{mM}$ while maintaining a constant $\mathrm{pH}$ of 7 (see Table 4 and Figure 2). At $1 \mathrm{mM}$ concentration, $\mathrm{K}_{2} \mathrm{HPO}_{4}$ produced higher purity than TEAB (90.8\% vs. $86.1 \%$ ). TEAB, on the other hand, outperformed $\mathrm{K}_{2} \mathrm{HPO}_{4}$ by $5.4 \%$ in yield. At $10 \mathrm{mM}$ concentration, TEAB produced $5.1 \%$ more purity than $\mathrm{K}_{2} \mathrm{HPO}_{4}$; nevertheless, TEAB produced $4.1 \%$ less yield than $\mathrm{K}_{2} \mathrm{HPO}_{4}$. Buffer $\mathrm{K}_{2} \mathrm{HPO}_{4}$ had around $5.1 \%$ less purity than TEAB at $20 \mathrm{mM}$ concentration but had $2.8 \%$ higher yield. At $30 \mathrm{mM}$, TEAB has $6.0 \%$ higher purity than $\mathrm{K}_{2} \mathrm{HPO}_{4}$ and just $0.6 \%$ lower yield. Buffer $\mathrm{K}_{2} \mathrm{HPO}_{4}$ had $5.7 \%$ less purity than TEAB and $1.6 \%$ higher yield than $\mathrm{TEAB}$ at $40 \mathrm{mM}$. There were no significant variations in 
Table 4. Comparison of purity and yield for Oligonucleotide-A with different concentration values at a constant $\mathrm{pH}$ of 7 for $\mathrm{K}_{2} \mathrm{HPO}_{4}$ and TEAB.

\begin{tabular}{|c|c|c|c|c|}
\hline $\mathrm{pH}$ & Concentration, $\mathrm{mM}$ & Buffer & Purity, \% & Yield, \% \\
\hline \multirow{2}{*}{7} & \multirow{2}{*}{1} & $\mathrm{~K}_{2} \mathrm{HPO}_{4}$ & $86.1 \pm 0.9$ & 79.8 \\
\hline & & TEAB & $90.8 \pm 0.1$ & 74.4 \\
\hline \multirow{2}{*}{7} & \multirow{2}{*}{10} & $\mathrm{~K}_{2} \mathrm{HPO}_{4}$ & $87.5 \pm 0.4$ & 79.0 \\
\hline & & TEAB & $92.6 \pm 0.1$ & 74.9 \\
\hline \multirow{2}{*}{7} & \multirow{2}{*}{20} & $\mathrm{~K}_{2} \mathrm{HPO}_{4}$ & $87.7 \pm 0.3$ & 77.9 \\
\hline & & TEAB & $92.6 \pm 0.2$ & 75.1 \\
\hline \multirow{2}{*}{7} & \multirow{2}{*}{30} & $\mathrm{~K}_{2} \mathrm{HPO}_{4}$ & $87.1 \pm 0.1$ & 77.5 \\
\hline & & TEAB & $93.1 \pm 0.1$ & 74.9 \\
\hline \multirow{2}{*}{7} & \multirow{2}{*}{40} & $\mathrm{~K}_{2} \mathrm{HPO}_{4}$ & $86.9 \pm 0.2$ & 76.1 \\
\hline & & TEAB & $93.3 \pm 0.1$ & 74.5 \\
\hline
\end{tabular}

Note: Each value is obtained based on the average of three runs.

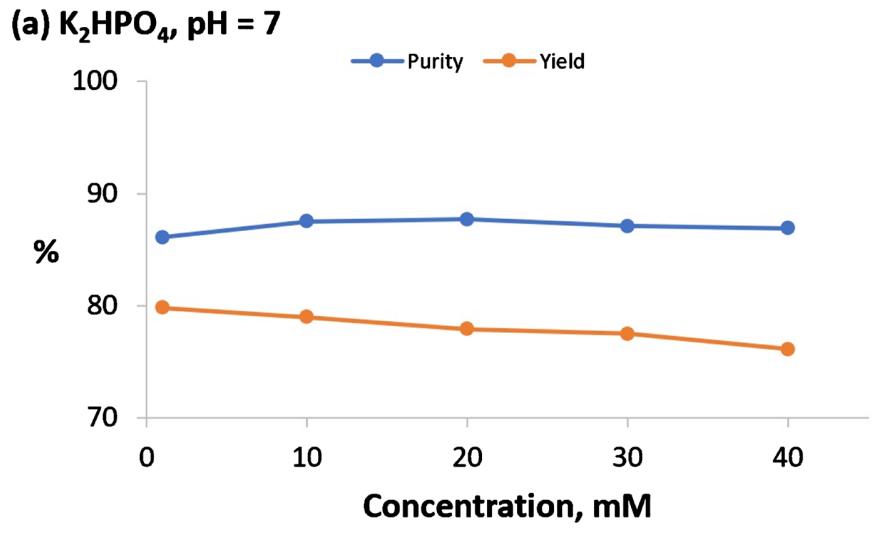

(b) TEAB, $\mathrm{pH}=7$

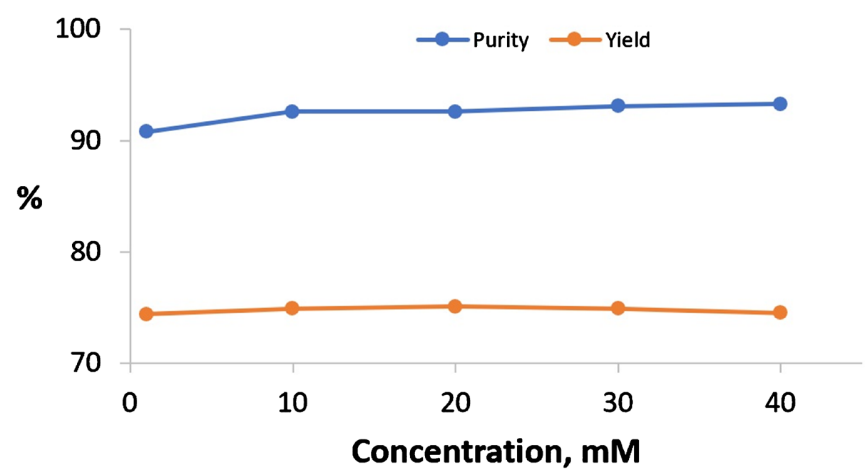

Figure 2. Comparison of the purity and yield percentages of $\mathrm{K}_{2} \mathrm{HPO}_{4}$ and TEAB with a constant $\mathrm{pH}$ of 7 and concentrations ranging from 1 to $40 \mathrm{mM}$.

purity or yield during $\mathrm{pH}$ tuning. However, increasing the concentration of $\mathrm{K}_{2} \mathrm{HPO}_{4}$ and TEAB had a greater impact on purity and yield. The drop-in yield during the $\mathrm{pH}$ experiment was not as extreme as the concentration decrease, but the purity 
increased dramatically.

The standard deviation was calculated based on all three experiments at each concentration level to measure the degree of variation. All concentrations were considered modest, although the data set's biggest standard deviation was at 1 $\mathrm{mM} \mathrm{K}_{2} \mathrm{HPO}_{4}$. With a standard deviation of 0.96 , this experiment had the largest standard deviation of all the experiments. The data set's lowest standard deviation was 0.10 , which was observed at $1 \mathrm{mM}$ and $10 \mathrm{mM}$ for TEAB.

\subsection{Mobile Phase Optimization}

To optimize oligonucleotide-A purification, two additional buffers, TEAA and $\mathrm{NH}_{4} \mathrm{CH}_{3} \mathrm{CO}_{2}$, were used in this study, and the experiment was performed at a constant $\mathrm{pH}$ of 7 and a constant concentration of $10 \mathrm{mM}$. The most change was generated by changing the nature of the buffer. Table 5 and Figure 3 show that TEAB had the highest purity at $92.6 \%$ (yield, $74.9 \%$ ), followed by TEAA at $90.6 \%$ (yield, $72.1 \%$ ), $\mathrm{K}_{2} \mathrm{HPO}_{4}$ at $87.5 \%$ (yield, $79.0 \%$ ), and $\mathrm{NH}_{4} \mathrm{CH}_{3} \mathrm{CO}_{2}$ at $84.3 \%$ (yield, 69.9\%). According to the published literature [1], 88.0\% purity and $80.0 \%$ yield were obtained by HPLC using $\mathrm{K}_{2} \mathrm{HPO}_{4}$ buffer at $\mathrm{pH} 7(10 \mathrm{mM})$, while in this experiment, $\mathrm{K}_{2} \mathrm{HPO}_{4}$ purity was $87.5 \%$ and yield was $79.0 \%$. There was a 5 -

Table 5. Comparison of purity and yield with different buffers at constant $\mathrm{pH} 7$.

\begin{tabular}{ccccc}
\hline $\mathrm{pH}$ & Concentration, $\mathrm{mM}$ & Buffer & Purity, \% & Yield, \% \\
\hline 7 & 10 & $\mathrm{~K}_{2} \mathrm{HPO}_{4}$ & $87.5 \pm 0.4$ & 79.0 \\
7 & 10 & TEAB & $92.6 \pm 0.1$ & 74.9 \\
7 & 10 & TEAA & $90.6 \pm 0$. & 72.1 \\
7 & 10 & $\mathrm{NH}_{4} \mathrm{CH}_{3} \mathrm{CO}_{2}$ & $84.3 \pm 0.5$ & 69.9 \\
\hline
\end{tabular}

Note: Each value is obtained based on the average of three runs.

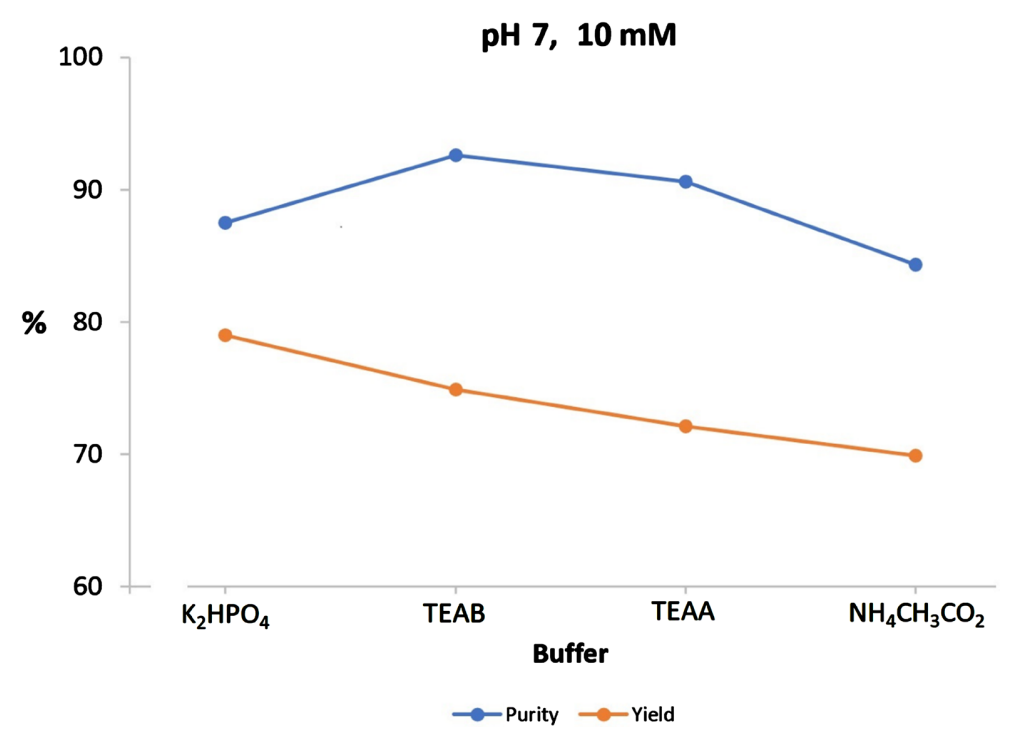

Figure 3. Comparison of the purity and yield percentages of four different buffers at constant $\mathrm{pH} 7$ and concentration of $10 \mathrm{mM}$. 
6 percent higher from the earlier reported approach when TEAB was used instead of $\mathrm{K}_{2} \mathrm{HPO}_{4}$, and a 2.6 percent increase when TEAA was used instead of potassium phosphate. In all situations, the yield was reduced. The use of $\mathrm{NH}_{4} \mathrm{CH}_{3} \mathrm{CO}_{2}$ reduced yield by $10.1 \%$. TEAA reduced production by $7.9 \%$, TEAB by $5.1 \%$, and potassium phosphate by $1 \%$. TEAB has the highest purity and yield of the four buffers tested; the purity is $5.4 \%$ greater than previously reported data, but the yield is lower. TEAB has the largest concentration, followed by TEAA and $\mathrm{NH}_{4}$ $\mathrm{CH}_{3} \mathrm{CO}_{2}$.

The standard deviation for the mobile phase experiment change was recorded, and the findings are shown in Table 5. The data set's largest standard deviation was 0.66 at $10 \mathrm{mM}$ TEAA. The data set's lowest standard deviation was 0.10 , which was seen at $10 \mathrm{mM}$ TEAB buffer.

\subsection{Optimization in Oligonucleotide-A Size}

With purity improved from 88 to 94 percent, further investigation into expanding the study to different oligonucleotide-A chain lengths was pursued. Chain lengths ranged from 20 to 40 oligonucleotide-A. The same optimized procedure was used to treat these chains with TEAB at a constant $\mathrm{pH}$ of 7 and a concentration of $40 \mathrm{mM}$. Table 6 and Figure 4 summarize the outcomes of these experiments. In

Table 6. Comparison of purity and yield with different Oligonucleotide lengths with constant $\mathrm{pH} 7$, concentration of $40 \mathrm{mM}$, and buffer TEAB.

\begin{tabular}{cccccc}
\hline Length & Buffer & pH & Concentration, mM & Purity, \% & Yield, \% \\
\hline Oligonucleotide-20 & TEAB & 7 & 40 & $92.6 \pm 0.2$ & 76.3 \\
Oligonucleotide-25 & TEAB & 7 & 40 & $93.3 \pm 0.4$ & 76.1 \\
Oligonucleotide-30 & TEAB & 7 & 40 & $93.7 \pm 0.1$ & 75.7 \\
Oligonucleotide-35 & TEAB & 7 & 40 & $93.9 \pm 0.3$ & 74.5 \\
Oligonucleotide-40 & TEAB & 7 & 40 & $94.0 \pm 0.2$ & 74.8 \\
\hline
\end{tabular}

Note: Each value is obtained based on the average of three runs.

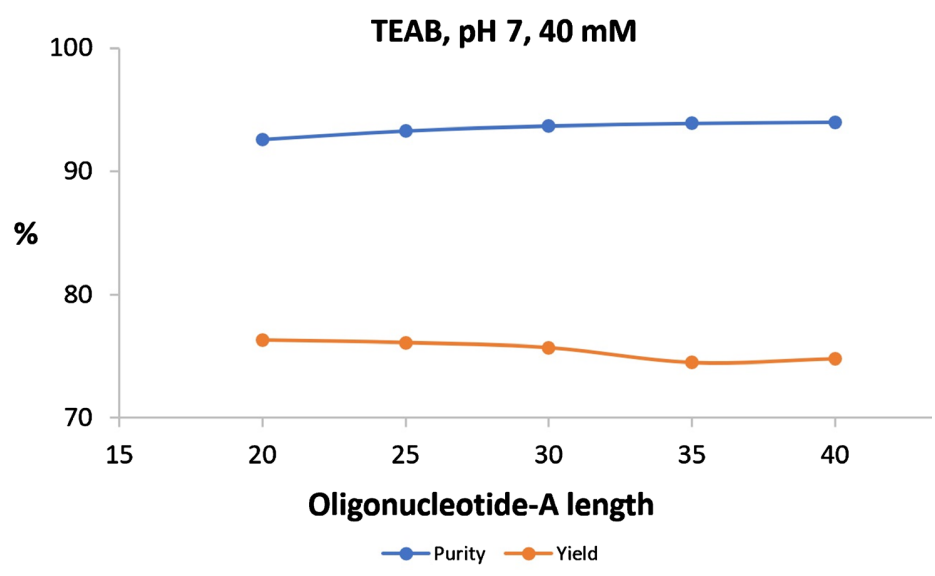

Figure 4. Comparison of purity and yield of Oligonucleotide-A lengths range from 20 to 40 with constant $\mathrm{pH} 7$, concentration of $40 \mathrm{mM}$, and buffer TEAB. 
chains longer than or equivalent to 30 oligonucleotide-A, the approach proved sufficient. Purity was found to be larger than the figure stated in the literature. The optimized process achieved a purity of $94 \%$ and a yield of $75 \%$.

\section{Conclusion}

The proposed approach for purifying oligonucleotide-A by HPLC was rapid, accurate, and precise. This method is based on the usage of a basic working procedure for an oligonucleotide-A chain that was tuned among several parameters based on purity and yield. The process was evaluated for oligonucleotides-A ranging from 25 - 40 nucleotides in length, utilizing HPLC capabilities in the laboratory, followed by rotary evaporation and lyophilization, and products were produced with a purity of 92 - 94 percent and a yield of 75 - 79 percent. Researchers can choose the best buffer and $\mathrm{pH}$ for their work based on the application and sensitivity of the work.

\section{Acknowledgements}

Authors would like to thank you Environmental Chemistry, Inc. in Houston, Texas for instrumentation.

\section{Conflicts of Interest}

The authors declare no conflicts of interest regarding the publication of this paper.

\section{References}

[1] Biba, M., Jiang, E., Mao, B., Zewge, D., Foley, J.P. and Welch, C.J. (2013) Factors Influencing the Separation of Oligonucleotides Using Reversed-Phase/Ion-Exchange Mixed-Mode High Performance Liquid Chromatography Columns. Journal of Chromatography $A, 1304,69-77$. https://doi.org/10.1016/j.chroma.2013.06.050

[2] Tosi, L., Sridhara, V., Yang, Y., Guan, D., Shpilker, P., Segata, N., Larman, H.B. and Parekkadan, B. (2017) Long-Adapter Single-Strand Oligonucleotide Probes for the Massively Multiplexed Cloning of Kilobase Genome Regions. Nature Biomedical Engineering, 1, Article No. 0092. https://doi.org/10.1038/s41551-017-0092

[3] Ahuja, S. and Alsante, K. (2003) Handbook of Isolation and Characterization of Impurities in Pharmaceuticals. 1st Edition, Academic Press, Cambridge.

[4] York, K.T., Smith, R.C., Yang, R., Melnyk, P.C., Wiley, M.M., Turk, C.M., Ronaghi, M., Gunderson, K.L. and Steemers, F.J. (2012) Highly Parallel Oligonucleotide Purification and Functionalization Using Reversible Chemistry. Nucleic Acids Research, 40, e4. https://doi.org/10.1093/nar/gkr910

[5] Zhang, Q.L., Lv, H.H., Wang, L.L., Chen, M., Li, F.F., Liang, C., Yu, Y.Y., Jiang, F., Lu, A.P. and Zhang, G. (2016) Recent Methods for Purification and Structure Determination of Oligonucleotides. International Journal of Molecular Sciences, 17, Article No. 2134. https://doi.org/10.3390/ijms17122134

[6] Gong, H., Holcomb, I., Ooi, A., Wang. X., Majonis. D., Unger. M.A. and Ramakrishnan, R. (2016) Simple Method to Prepare Oligonucleotide-Conjugated Antibodies and Its Application in Multiplex Protein Detection in Single Cells. Bioconjugate Chemistry, 27, 217-225. https://doi.org/10.1021/acs.bioconjchem.5b00613 
[7] Pinto, A., Chen, S.X. and Zhang, D.Y. (2018) Simultaneous and Stoichiometric Purification of Hundreds of Oligonucleotides. Nature Communications, 9, Article No. 2467. https://doi.org/10.1038/s41467-018-04870-w

[8] Cohen, A.S., Najarian, D.R., Paulus, A., Guttman, A., Smith, J.A. and Karger, B.L. (1988) Rapid Separation and Purification of Oligonucleotides by High-Performance Capillary Gel Electrophoresis. Proceedings of the National Academy of Sciences of the United States of America, 85, 9660-9663.

https://doi.org/10.1073/pnas.85.24.9660

[9] Guttman, A., Cohen, A.S., Heiger, D.N. and Karger, B.L. (1990) Analytical and Micropreparative Ultrahigh Resolution of Oligonucleotides by Polyacrylamide Gel High-Performance Capillary Electrophoresis. Analytical Chemistry, 62, 137-141. https://doi.org/10.1021/ac00201a010

[10] Quarry, M.A., Grob, R.L. and Snyder, L.R. (1986) Prediction of Precise Isocratic Retention Data from Two or More Gradient Elution Runs. Analysis of Some Associated Errors. Analytical Chemistry, 58, 907-917. https://doi.org/10.1021/ac00295a056

[11] Krupczyńska, K. and Buszewski, B. (2004) Chromatographic Methods Can Characterize Stationary Phases without Destroying Them. Analytical Chemistry, 76, 226A234A. https://doi.org/10.1021/ac041583o

[12] Jandera, P., Hájek, T. and Šromová, Z. (2018) Mobile Phase Effects in Reversed-Phase and Hydrophilic Interaction Liquid Chromatography Revisited. Journal of Chromatography $A, 1543,48-57$.

[13] Van de Ven, H.C., Gargano, A.F., van der Wal, S. and Schoenmakers, P.J. (2015) Switching Solvent and Enhancing Analyte Concentrations in Small Effluent Fractions Using In-Column Focusing. Journal of Chromatography A, 1427, 90-95. https://doi.org/10.1016/j.chroma.2015.11.082

[14] Schellinger, A.P. and Carr, P.W. (2006) Isocratic and Gradient Elution Chromatography: A Comparison in Terms of Speed, Retention Reproducibility and Quantitation. Journal of Chromatography A, 1109, 253-266. https://doi.org/10.1016/j.chroma.2006.01.047

[15] Vyňuchalová, K. and Jandera, P. (2011) Selectivity Tests of Stationary Phases for Reversed-Phase HPLC. Analytical Letters, 44, 1640-1662.

https://doi.org/10.1080/00032719.2010.520393

[16] Wiczling, P., Markuszewski, M.J., Kaliszan, M. and Kaliszan, R. (2005) pH/Organic Solvent Double-Gradient Reversed-Phase HPLC. Analytical Chemistry, 77, 449-458. https://doi.org/10.1021/ac049092r

[17] Ogawa, T. (2013) Protein Engineering: Technology and Application. 1st Edition, InTech, Rijeka. https://doi.org/10.5772/3363

[18] Gargano, A.F., Duffin, M., Navarro, P. and Schoenmakers, P.J. (2016) Reducing Dilution and Analysis Time in Online Comprehensive Two-Dimensional Liquid Chromatography by Active Modulation. Analytical Chemistry, 88, 1785-1793. https://doi.org/10.1021/acs.analchem.5b04051 